Cahiers $d u$ MONDE RUSSE

\section{Cahiers du monde russe}

Russie - Empire russe - Union soviétique et États indépendants

50/2-3 | 2009

L'Europe orientale, 1650-1730. Crises, conflits et renouveau

\title{
Clubs politiques et perestroïka en RussieCarole SIGMAN
}

, Paris : Karthala, 2009, 476 p.

\section{Graeme Gill}

\section{(2) OpenEdition}

\section{Journals}

Édition électronique

URL : https://journals.openedition.org/monderusse/9776

DOI : 10.4000/monderusse. 9776

ISSN : $1777-5388$

\section{Éditeur}

Éditions de l'EHESS

\section{Édition imprimée}

Date de publication : 15 septembre 2009

ISBN : 978-2-7132-2260-3

ISSN : $1252-6576$

\section{Référence électronique}

Graeme Gill, «Clubs politiques et perestroika en RussieCarole SIGMAN », Cahiers du monde russe [En ligne], 50/2-3 | 2009, mis en ligne le 14 janvier 2013, consulté le 03 septembre 2022. URL : http:// journals.openedition.org/monderusse/9776; DOI : https://doi.org/10.4000/monderusse.9776

Ce document a été généré automatiquement le 3 septembre 2022

Tous droits réservés 


\section{Clubs politiques et perestroïka en RussieCarole SIGMAN}

, Paris : Karthala, 2009, 476 p.

Graeme Gill

\section{Carole SIGMAN, Clubs politiques et perestroïka en Russie, Subversion sans dissidence, Paris : Karthala, 2009, 476 p.}

Carole Sigman has written an excellent book on the informal movement in Moscow and the way it changed over the course of perestroika and into post-Soviet Russia. Her focus is on clubs which initially emerged out of official organs in Moscow, often at the party raikom level, and she charts their development against the background of what she sees as the multiplication of arenas for political action in the late 1980s-early 1990s. Sigman identifies two waves of clubs, the first emerging in 1986-1987, and the second in the latter half of 1988. The first wave was led by people born between 1948 and 1964. Many of them had been educated in the social sciences, had been exposed to heterodox political ideas (e.g. through samizdat), and often had a background in professional research activity. Some former dissidents were also involved. This first wave sought cooperation with reformers in the party to press for the radicalization of Gorbachev's reform program, often relying heavily on sympathy within the local party organization for access to the resources necessary to mount their political activities. Rather than an opposition, they effectively played the role of a ginger group, although they were consistently opposed to the more conservative elements in the party. They were therefore always subject to tension about the sort of relationship they should have with the party reformers, a tension which sometimes led to organizational splits. The second cohort of activists was generally older, with many being born between 1937 and 1948. They were more likely to have been educated in science or engineering, had been less exposed to heterodox political ideas, and often came from a career in the party or other official structure. They became political activists when the potential costs of doing so were not as high as for the first wave, and often were recruited into the movement through the public demonstrations and meetings following the XIX Conference. But they adopted a more 
radical stance than the earlier cohort and made use of the opportunities for political activism that opened up from mid-1988. They made use of street demonstrations, exploited the electoral opportunities created by the elections of 1989 and 1990, transformed the clubs into nascent parties, and moved into an oppositional position behind Yeltsin. Rather than seeking to work with the moderate reformers around Gorbachev, they cast in their lot with those seeking more radical change. The role and development of the Democratic Platform within the Communist Party is one such group discussed in the book. It was these groups which constituted the initial base of the postSoviet Russian party system.

2 This is a stimulating line of argument and adds significantly to our understanding of the grassroots dynamic of this period. It is particularly useful in the way in which it illustrates the course of development of a social movement, and how that course of development was shaped by the institutional opportunity structure that unfolded under perestroika. The clubs began as autonomous actors within the official structures which were at the time the only legitimate arenas for political activity, but then when such arenas expanded, the nature of the social movement changed to take advantage of the new opportunities. The influx of new people into the movement at the same time was also instrumental in this change, what Sigman sees as the shift from the informal movement to the democratic opposition. What is not clear in the book is the extent to which this shift was a function of each of these factors. While it would clearly be difficult to assign responsibility accurately, a systematic study of the fate of the first cohort of leaders after mid-1988 might have given some sense of this. But even accepting the lack of clarity here, the shift itself was clearly important both for the movement itself and for the fate of Russia. In particular with regard to the latter, the development of diverse "party" groups which remained fractious and disputative, contributed significantly to the inability of an umbrella organ like the national fronts in the Baltic to emerge in Russia. This in turn may have been a factor in the instability of Russian politics in the early 1990s. In this sense, the political trajectory of the club movement, as Sigman shows, had implications for the shaping of post-Soviet Russian politics.

3 While this is an excellent study, two qualifications should be noted. The first relates to the personnel data upon which Sigman bases her summaries of the two activist cohorts. In both cases, she has relevant information about only half of the activists, and while this is not an insignificant proportion, a higher percentage would have given greater substance to her findings. Second, the study only looks at those clubs which supported reform and which were to extend into the democratic camp, and which were active in Moscow. Accordingly more conservative groups, referred to by Sigman as "nationalists and Stalinists," are ignored. For example, both Pamiat and the Marxist Platform, while mentioned, are given no sustained analysis, and although Pamiat stemmed from before the perestroika period, the role it played seems sufficiently similar as to constitute a useful counterpoint. The Marxist Platform was a direct competitor of the Democratic Platform. Furthermore the exclusive focus on clubs which emerged from the interstices of official bodies means that something like the Democratic Union, which was far more radical from the outset than any of the bodies discussed in the book, is not analyzed. Nor are groups that emerged outside Moscow. The result of these omissions is that the book does not give a complete picture of the spectrum of political opinion in informal Moscow, let alone the Soviet Union as a whole, during this time. However, despite this, the book is an excellent study of the reformist wing of the Moscow informal movement 
and is highly recommended for anyone wanting to understand the grassroots of the perestroika period. 